\title{
Analysis of Logical-Mathematical Intelligence Profile on Application of Problem-Based Learning on Acid- Base
}

\author{
Sri Wardani ${ }^{1}$, Laras Kurniawati ${ }^{2}$ \\ $\left\{\right.$ menuksriwardani@gmail.com $\left.{ }^{1}\right\}$ \\ Chemistry Departement, Mathematics and Natural Science Faculty, Universitas Negeri Semarang ${ }^{1,2}$

\begin{abstract}
Lack of problem solving ability is caused by students' logical and mathematical thinking intelligence not honed, so that problem solving abilities and logical thinking is low. This results in student learning outcomes, as many as $75 \%$ of students do not pass KKM on acid-base. The study aims to analyze the profile of logical-mathematical intelligence in class XI SMA Islam Sudirman Ambarawa. The study was used mix methods sequential explanatory to explain the result of research and used purposive sampling technique with 34 samples, class XI MIA 2. The research describes aspects of intelligence, the aspects are the ability to calculating process and mathematical operations. The results of the study stated that the achievement of logical-mathematical intelligence in XI MIA 2 reached $60 \%$. As many as 3 outs have very good intelligence with a percentage of $9 \%$, while for sufficient and poor categories $76 \%$ and $15 \%$ respectively. It can be concluded that the application of problem-based learning trains active students in learning and trains students' problem-solving skills through steps of problem-based learning. Student's problem-solving abilities influence cognitive abilities so that the profile of students' logical-mathematical intelligence after the application of problem-based learning reaches good enough category of logical-mathematical intelligence.
\end{abstract}

Keywords: logical-mathematical intelligence; problem based learning

\section{Introduction}

Indonesian education is implemented and regulated based on a set of rules called a curriculum. The 2013 curriculum emphasizes the student-centered learning process. Students as active components in the learning process in the classroom in accordance with Law No. 22 of 2016. The 2013 curriculum calls for the learning process for high school levels to be carried out using a scientific approach. The scientific approach (scientific approach) is a process that adopts scientific steps in building students' knowledge through scientific methods (Sufairoh, 2016). The scientific approach is strengthened by the application of problem-based learning (PBL), project-based learning (PJBL), and research-based learning namely discovery and inquiry learning. Learning models can be implemented on learning media as a learning resource for students. One source of learning that is often used by teachers and students is student worksheets (Musfiqon \& Nurdyansyah, 2015). 
Learning outcomes for each individual is different. This difference is caused by the problem solving steps and thinking patterns of each individual is different. Irvaniyah \& Akbar (2014) stated that in solving problems we are required to think and work hard to accept challenges to be able to solve problems faced. Problem-solving needs to be planned on what steps must be taken to solve the problem systematically. Every student completes a problem has different ways depending on the level of cognitive abilities. Cognitive ability is the ability of students in the process of thinking, reasoning, and the ability of students to solve a problem. Different levels of cognitive abilities make the intelligence of each student also different (Ulya, 2015).

The level of cognitive ability is often associated with logical intelligence and problem solving abilities (Sihaloho et al., 2017). A person with good logical-mathematical (LM) intelligence is able to analyze the cause and effect of something and is able to formulate existing problems so that someone with LM intelligence can think rationally in logic. LM intelligence is considered to have the ability in terms of thinking inductively and deductively, thinking according to the rules of logic, understanding and analyzing patterns of numbers, and the habit of solving problems using thinking skills. Each student has a different level of LM intelligence. This difference causes the learning outcomes obtained by each student to be different (Susanti, 2018).

Preliminary studies conducted on students in one senior high schools in Ambarawa showed that the completeness of the results of even semester chemistry test scores in 2018 in the class amounted to approximately $25 \%$, only 34 out of 135 students fulfilled the KKM completeness value of 75. Based on observations of the process learning in class XI MIPA in the high school, the learning that has been done has not utilized the learning model according to the applicable curriculum in 2013. The teacher said that students have problem-solving abilities that are less seen in how students answer questions. Descriptive questions require a complete process with mathematical calculations and logical thinking to solve them so that, the teacher knows the level of understanding of students. Students are also less able to analyze the intent of the problem and tend not to be able to answer questions with $\mathrm{C} 4$ cognitive level sequentially and sequentially so that counting errors and concepts often occur. Another factor that causes low classical value is the lack of face-to-face hours which results in the teacher wanting to be impressed to hurry to complete the material so that all material can be completed on time. In this case, the subject matter cannot yet be conveyed in its entirety to students, which of course has an effect on the level of students' understanding of the material.

Based on the description above, researchers conducted a study to analyze the profile of students' logical-mathematical intelligence on the application of problem-based learning. The research was conducted at SMA Islam Sudirman Ambarawa with mix methods research.

\section{Method}

This research use mix methods sequential explanatory conducted in SMA Islam Sudirman Ambarawa. The study was conducted in the even semester of the 2018/2019 academic year on acid-base. The population in this study were all students of class XI MIA SMA Islam Sudirman Ambarawa consisting of four classes totaling 137 students. The sample in this study was class XI MIA 2. Samples were selected by purposive sampling technique that is taking selected research samples with specific considerations and objectives (Cresswell, 2014). The study was conducted by the application of problem-based learning. 
Data collection techniques are carried out by tests, interviews, and documentation. The interview technique at the initial stage was carried out to identify problems before the study. documentation is done to collect student name data, photos of learning activities, and photos of products made by students. The test was done once, it is posttest to measure students' logical-mathematical intelligence. The interview technique is also used to find out students' logical-mathematical intelligence more deeply. Data analysis in this study used statistical tests to measure instrument reliability and measure logical-mathematical logical intelligence. The analysis was also carried out in a descriptive explanatory way to describe students' logicalmathematical intelligence.

\section{Results and Discussion}

The profile of logical-mathematical intelligence is measured using description questions that are made based on aspects of logical-mathematical intelligence, namely the ability of the calculation process and mathematical operations ability. The Research applies a problembased learning model that is intended so that students can hone their intelligence. The step is to increase the activeness of students in the class because conventional learning models only peg students to receive information that demands memorization so that students are less or weak in using their thinking skills when completing the chemical aids charged to them. Problem-based learning in this study is aided by problem-based media student worksheets. Students are guided to solve problems and find problems according to the problem-based syntax of learning (Yew and Goh, 2016). The results of the analysis of students' logicalmathematical intelligence can be seen in Table 1.

Table 1. Profile of Logical-Mathematical Intelligence

\begin{tabular}{|c|c|c|}
\hline Criteria & Students & Percentage (\%) \\
\hline Very Good (VG) & 3,0 & 9,0 \\
\hline Good (G) & 0,0 & 0,0 \\
\hline Sufficient (S) & 26,0 & 76,0 \\
\hline Poor (P) & 5,0 & 15,0 \\
\hline Total & 34,0 & 100,0 \\
\hline
\end{tabular}

Based on Table 1, the profile of students' logical-mathematical intelligence classically, namely 3 people from 34 students had very good logical-mathematical intelligence, while for good, sufficient and poor categories respectively were 0,26 and 5 people from 34 students. The percentage of achievement in each category of very good, good, sufficient, and poor in a row is $9 \%, 0 \%, 76 \%, 15 \%$. The achievement of students' intelligence on aspects of the calculation process and mathematical operations is presented in Figure 1. 


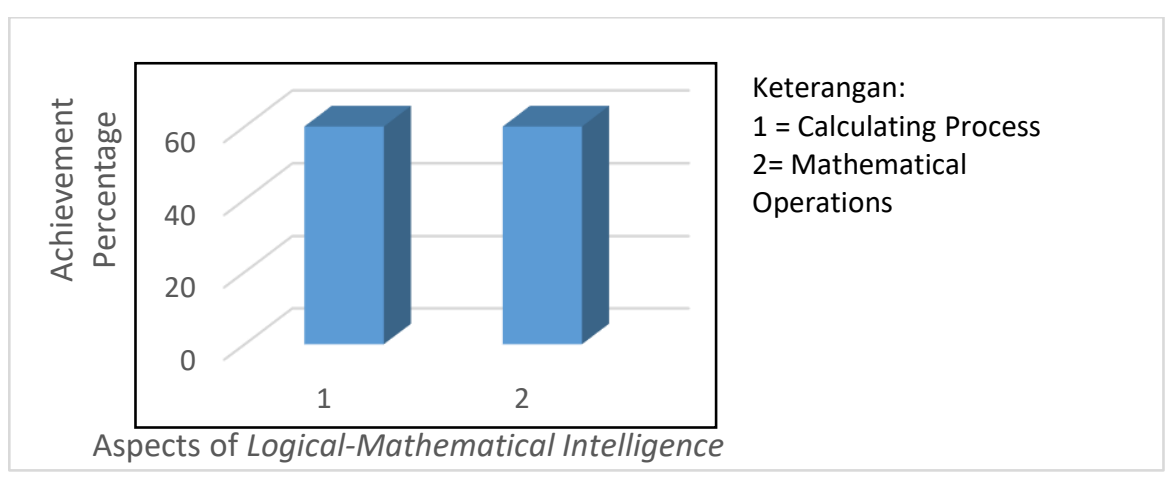

Figure 1. Achievement of logical-mathematical intelligence in every aspect

\subsection{Aspect of Calculation Process Ability}

The aspect of calculation ability is calculating what is learned in creative and unusual ways to create something new and deal with everyday problems (Lazear, 2004). The calculating process in this study was developed again into 3 indicators, namely communicating the problem into mathematical ideas, performing a computational process that is coherent, and liking complex calculation patterns (Aminah \& Siska, 2015).

Achievement of the calculating process aspects is influenced by the three indicators concerned. The aspect of the calculation process consists of 3 indicators as measured by description test questions. Each indicator consists of 1 question with a maximum score of 4 , so that if the highest achievement of students is $100 \%$ if it reaches a score of 12 in this aspect. The results of the percentage of intelligence achievement in indicators 1, 2 and 3 are $70 \%$, $71 \%$, and $68 \%$ respectively. Based on the results, it can be seen that the third indicator has the lowest achievement and the second indicator has the highest achievement. The indicator with the lowest achievement is to like a complex calculation pattern, while the indicator with the highest achievement is to carry out a coherent calculation process.

The statement on the third indicator is to like complex calculation patterns. Complex calculations can be in the form of a combination of several formulas and concepts to produce an appropriate conclusion. Complex calculations require a level of problem analysis and communicating the question in its mathematical form. The low achievement of students on this indicator can be caused by several factors, one of the factors is the lack of students' ability to analyze questions and communicate information in questions with concepts that have been studied (Yuliati et al., 2018).

Application of problem-based learning model, students are more critical, independent, have high curiosity so that their knowledge is accidentally constructed. Problem-based learning provides opportunities for students to learn from real and meaningful problems that are carried out through investigation or investigation. In addition, the PBL syntax applied in the student's worksheet indirectly affects the problem solving process (Pratiwi, 2015). In this case, the calculation process is part of the problem solving process. In the investigation step, students are asked to look for data on the problem and find out the correct calculation process if the problems encountered can be calculated in value. Through this stage of the investigation, students' process skills can be honed primarily in their ability to process numeracy and other mathematical operations (Risdianti, 2017; Kaharuddin, 2018). 


\subsection{Aspect of Mathematical Operations.}

The mathematical operations ability in this study relates to applying and integrating mathematical operations to solve problems in everyday life. The aspects of mathematical ability in this study were measured by tests using description questions consisting of 3 questions adapted from 3 indicators of mathematical abilities. Indicator of mathematical ability used is being able to connect everyday problems with mathematical concepts, conclude with mathematical language, and solve everyday problems using mathematical concepts (Kholidah, 2018).

Indicator achievement in the aspect of mathematical operations is $97 \%, 52 \%, 68 \%$. Based on these results, one indicator has a high achievement of $97 \%$ and the lowest achievement of $53 \%$. The highest achievement is achieved by indicators solving everyday problems with mathematical concepts. The lowest achievement is achieved by mathematical communication indicators, the ability to describe questions into mathematical forms and draw conclusions mathematically.

Indicator of mathematical operations abilities that getting the lowest achievement is mathematical communication skills. Mathematical communication skills in question are the ability to convey mathematical ideas both orally and in writing. In this study, the mathematical ability indicator was assessed through a test with a description question where students were asked to draw the $\mathrm{pH}$ value of waste solutions $\mathrm{A}$ and $\mathrm{B}$ in mathematical language based on the route data indicators that have been presented. Achievement in this indicator is low because students do not change the conclusions obtained into mathematical languages, students only write conclusions in simple language or just rewrite the results in numbers way. Based on interviews, students were also still confused about estimating and processing information from several $\mathrm{pH}$ route data to achieve a correct $\mathrm{pH}$ number. Mathematical communication skills are related to mathematical operating abilities. Mathematical communication skills are devoted to the ability to use mathematical and non-mathematical languages in solving essay's problems. This communication ability will determine the level of students' ability to express both symbolic and narrative mathematics in the process or steps in completing the story problem (Polya, 1973). Mathematical communication skills affect students' cognitive styles and problem solving (Haryani et al., 2018). This was also stated by Achir et al (2017) who stated that mathematical communication skills of students were able to explain the situation, were able to present problems, were able to represent mathematics as a whole and separate, were able to use concepts and strategies, be able to solve problems, be able to get solutions, and be able interpret the solution.

Problem-based learning provides opportunities for students to learn from real and meaningful problems that are carried out through investigation or investigation. The syntax of problem-based learning applied in student's worksheet indirectly influences the problem solving process (Argaw et al., 2017). In this case, the aspects of the calculating process and mathematical operations are part of the problem-solving process. In the investigation step students are asked to look for data on the problem and find out the correct calculation process if the problems encountered can be calculated in value. Through those stage of investigation, students' process abilities can be honed, primarily in their ability to calculating process and other mathematical operations (Risdianti, 2017). Through problem-based student's worksheet, students are taught to be able to connect everyday problems with mathematical concepts, get used to answering mathematical questions with mathematical communication, solve problems using mathematical formulas or concepts, and relating the daily problems with appropriate theory (Kaharuddin, 2018). 
Problem-based learning aided by problem-based student's worksheet trains students to be accustomed to performing sequential problem solving stages and are forced to use their logic to solve problems. This is in line with the research conducted by Fauzi \& Monawati (2018) that students with good LM's intelligence can do the stages of problem-based learning well so that logical-mathematical intelligence is good (Wewe, 2017). This statement is also supported by the research conducted by Sumartini (2015), that reasoning ability and ability to analyze students' problems using problem-based learning is better than students taught using conventional learning (Wartono et al., 2018). Problem-based learning has a significant influence on student motivation and learning outcomes, so learning outcomes increase and students' logical-mathematical intelligence reaches $60 \%$. This is in line with the research conducted by Surif et al (2013) which states that problem-based learning needs to be applied to the learning process to develop student skills and student learning outcomes.

\section{Conclusion}

The students were insufficient category of logical-mathematical intelligence. There were 26 students in sufficient category, meanwhile 3 students were in very good category. There was no students with good category, but there were 5 students in poor category. On another side, the achievement of logical-mathematical intelligence in both aspects is $60 \%$. The intelligence's percentage of each criterion in the category of very good, good, sufficient, and poor consecutively is $9 \%, 0 \%, 76 \%, 15 \%$. Based on the research it can be concluded that the application of problem-based learning trains active students in learning and trains students' problem solving skills through steps in the syntax of problem-based learning. Students' problem solving abilities influence cognitive abilities. Those cognitive abilities affect students' logical-mathematical intelligence. 


\section{References}

[1] Achir, Y.S., Usodo, B., \& Setiawan, R. (2017). Analisis Kemampuan Komunikasi Matematis Siswa dalam Pemecahan Masalah Matematika Pada Materi Sistem Persamaan Linear Dua Variabel (SPLDV) Ditinjau dari Gaya Kognitif. Paedagogia. Jurnal Penelitian Pendidikan. 20 (1), 78-87.

[2] Aminah, Neneng,. \& Siska, F. (2015). Keterampilan Proses Berfikir Matematika Mahasiswa Ditinjau dari Performance Assesment. Euclid, 3 (2), 474-603.

[3] Argaw, A. S., Haile, B. B., Ayalew, B. T., Kuma, S. G. (2017). The Effect of Problem Based Learning (PBL) Instruction on Students' Motivation and Problem Solving Skills of Physics. Eurasia Journal of Mathematics, Science and Technology Education, 13(3), 857-871.

[4] Cresswell, John. C,. (2014). RESEARCH DESIGN: Qualitative, Quantitative, and Mixed Methods Approaches, Fourt Edition. SAGE Publication.

[5] Fauzi \& Monawati, 2018, Hubungan Antara Kecerdasan Logis Matematika dan Kedisiplinan Belajar Siswa Kelas V SD Negeri 1 Pagar Air Kabupaten Aceh Besar, Jurnal Pesona Dasar, 6 (1), 55-62.

[6] Haryani, S., Masfufah, Wijayati, N., \& Kurniawan, C. (2018). Improvement of Metacognitive Skills and Students' Reasoning Ability Through Problem Based Learning. J. Phys.: Conf. Ser. 983012174

[7] Irvaniyah, I., \& Akbar, R.O, 2014, Analisis Kecerdasan Logis Matematis dan Kecerdasan Linguistik Peserta didik berdasarkan Jenis Kelamin : Studi Kasus pada Peserta didik XI IPA MA Mafatihul Huda, EduMa. 3(1), 138-158.

[8] Kaharuddin, A. (2018). Effect of Problem Based Learning Model on Mathematical Learning Outcomes of $6^{\text {th }}$ Grade Students of Elementary School Accredited B in Kendari City. International Journal of Trends in Mathematics Education Research. 1 (2), 43-46.

[9] Kholidah, I.R., \& AA. Sujadi. 2018. Analisis Pemahaman Konsep Matematika Peserta didik Kelas V dalam Menyelesaikan Soal di SD Negeri Gunturan Pandak Bantul Tahun Ajaran 2016/2017. Trihayu: Jurnal Pendidikan Ke-SD-an, 4 (3), 428-431.

[10] Lazear, D. (2004). Higher- Order Thinking The Multiple Intelligences Way. Chicago: Zephyr Press.

[11] Musfiqon, H. M.,\& Nurdyansyah, 2015, Pendekatan Pembelajaran Saintifik. Sidoarjo: Nizamia Press.

[12] Polya, G. (1973). How To Solve It (A New Aspect of Mathematical Method). New: Jersey Princeton University Press.

[13] Pratiwi, D.D. (2015). Analisis Kemampuan Komunikasi Matematis dalam Pemecahan Masalah Matematika Sesuai dengan Gaya Kognitif dan Gender. Al Jabar: Jurnal Pendidikan Matematika, 6(2), 131-141.

[14] Risdianti, S.R. (2017). Peningkatan Kemampuan Operasi Hitung Penjumlahan dan Pengurangan Menggunakan Metode Problem Based Learning (PBL) Pada Anak Tunarungu Kelas III SD Wiyata Dharma 1 Sleman. Jurnal Widia Ortodidaktika, 6 (4),349-360.

[15] Sihaloho, R.R, Sahyar, \& Ginting, E.M. (2017).The Effect of Problem Based Learning (PBL) Model toward Student's Creative Thinking and Problem Solving Ability in Senior High School. IOSR Journal of Research \& Method in Education. 7 (4), 11-18.

[16] Sufairoh. (2016). Pendekatan Saintifik \& Model Pembelajaran K-13, Jurnal Pendidikan Profesional. 5 (3), 116-125.

[17] Sumartini, T.S. (2016). Peningkatan Kemampuan Penalaran Matematis Siswa Melalui Pembelajaran Berbasis Masalah, Jurnal Pendidikan Matematika. 5 (1), 148-158.

[18] Surif, J., Ibrahim, N.H \& Mokhtar, M. (2013). Implementation of Problem Based Learning in Higher Education Institutions and Its Impact on Students' Learning. The 4th International Research Symposium on Problem-Based Learning. Malaysia: Universiti Teknologi Malaysia, 66-73. 
[19] Susanti, V.D. (2018). Analisis Kemampuan Kognitif dalam Pemecahan Masalah Berdasarkan Kecerdasan Logis-Matematis, Jurnal Matematika dan Pendidikan Matematika. 3 (1), 71-83.

[20] Ulya, Himmatul. 2015. Hubungan Gaya Kognitif dengan Kemampuan Pemecahan Masalah Matematika Siswa. Jurnal Konseling. 1(2).

[21] Wartono, W., Diantoro, M., \& Bartlolona, J. R. (2018). Influence of Problem Based Learning Learning Model on Student Creative Thinking on Elasticity Topics A Material. Jurnal Pendidikan Fisika Indonesia, 14(1), 32-39.

[22] Wewe, M. (2017).The Effect of Problem Based Learning Model and Mathematic-Logical Intelligence Towards Mathematics Learning Achievement. Journal of Education Technology. $1(1), 7-17$.

[23] Yew, E.H.J \& Goh, K,. (2016). Problem-Based Learning: An Overview of its Process and Impact on Learning. IOSR Journal of Research \& Method in Education. 2,75-79.

[24] Yuliati, S., \& Lestari, I. (2018). Higher Order Thingking Skills (HOTS) Analysis of Students in Solving HOTS Question in Higher Education. Perspektif Ilmu Pendidikan, 32(2), 181 - 188. 